Full length article

\title{
Silk-based biomaterials functionalized with fibronectin type II promotes cell adhesion
}

\author{
Ana Margarida Pereira a,b,c,1, Raul Machado ${ }^{a, 1, *}$, André da Costa ${ }^{a}$, Artur Ribeiro ${ }^{a}$, Tony Collins ${ }^{a}$, \\ Andreia C. Gomes ${ }^{a}$, Isabel B. Leonor ${ }^{\text {b,c }}$, David L. Kaplan ${ }^{\mathrm{d}}$, Rui L. Reis ${ }^{\mathrm{b}, \mathrm{c}}$, Margarida Casal ${ }^{\mathrm{a}, *}$ \\ ${ }^{a}$ CBMA (Centre of Molecular and Environmental Biology), Department of Biology, University of Minho, Campus de Gualtar, 4710-057 Braga, Portugal

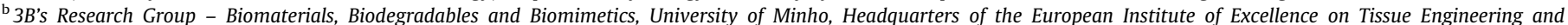 \\ Regenerative Medicine, AvePark, 4806-909 Taipas, Guimarães, Portugal \\ 'ICVS/3B's - PT Government Associate Laboratory, Braga/Guimarães, Portugal \\ ${ }^{\mathrm{d}}$ Department of Biomedical Engineering, Tufts University, Medford, MA 02155, USA
}

\section{A R T I C L E I N F O}

\section{Article history:}

Received 28 April 2016

Received in revised form 20 September

2016

Accepted 2 October 2016

Available online 3 October 2016

\section{Keywords:}

Fibronectin type II

Cell adhesion

Silk

Elastin

Biomaterials

\begin{abstract}
A B S T R A C T
The objective of this work was to exploit the fibronectin type II (FNII) module from human matrix metalloproteinase- 2 as a functional domain for the development of silk-based biopolymer blends that display enhanced cell adhesion properties. The DNA sequence of spider dragline silk protein (6mer) was genetically fused with the FNII coding sequence and expressed in Escherichia coli. The chimeric protein 6 mer + FNII was purified by non-chromatographic methods. Films prepared from $6 \mathrm{mer}+$ FNII by solvent casting promoted only limited cell adhesion of human skin fibroblasts. However, the performance of the material in terms of cell adhesion was significantly improved when 6 mer + FNII was combined with a silk-elastin-like protein in a concentration-dependent behavior. With this work we describe a novel class of biopolymer that promote cell adhesion and potentially useful as biomaterials for tissue engineering and regenerative medicine.
\end{abstract}

\section{Statement of Significance}

This work reports the development of biocompatible silk-based composites with enhanced cell adhesion properties suitable for biomedical applications in regenerative medicine. The biocomposites were produced by combining a genetically engineered silk-elastin-like protein with a genetically engineered spider-silk-based polypeptide carrying the three domains of the fibronectin type II module from human metalloproteinase-2. These composites were processed into free-standing films by solvent casting and characterized for their biological behavior. To our knowledge this is the first report of the exploitation of all three FNII domains as a functional domain for the development of bioinspired materials with improved biological performance. The present study highlights the potential of using genetically engineered protein-based composites as a platform for the development of new bioinspired biomaterials.

() 2016 Acta Materialia Inc. Published by Elsevier Ltd. All rights reserved.

\section{Introduction}

Recombinant protein-based polymers (rPBPs) are a class of biomaterials with unique chemical, physical and biological characteristics of interest particularly for tissue engineering [1,2]. Within the class of rPBPs, silk-like polymers (SLP) are being utilized in a range of studies in materials science. For instance, silk fibroin from

\footnotetext{
* Corresponding authors.

E-mail addresses: raulmachado@bio.uminho.pt (R. Machado), mcasal@bio, uminho.pt (M. Casal).

1 These authors contributed equally to this work.
}

the silkworm Bombyx mori has been processed into different structures to create various biomaterials such as films, fibres, hydrogels and porous sponges $[3,4]$. Spider silks such as the dragline silk from Nephila clavipes have been extensively studied due to their outstanding mechanical properties and thermal stability [4,5]. This particular spider silk is composed of two major proteins, major ampullate spidroin 1 (MaSp1) and major ampullate spidroin 2 (MaSp2) [6,7].

Recombinant spider silks functionalized with bioactive domains highlight the potential of these chimeric proteins for new biomaterials with relevant features for biomedical applications [4,8-11]. 
Cell adhesion is one of the most important concerns when developing biomaterials for tissue engineering and regenerative medicine since it is essential for several cell-function mechanisms such as cell migration and proliferation, which are crucial for the assembly and maintenance of tissues [12-14].

As rPBPs can be manipulated at the genetic level, bioactive domains such as fibronectin can be introduced for improved biological performance $[15,16]$. Fibronectin is a multidomain/multifunctional glycoprotein of the extracellular matrix that binds to several members of the integrin receptor family, playing an important role in processes such as cell adhesion, migration and differentiation [17-19]. This disulfide-bounded dimeric protein consists of two subunits that each contain three types of modules: type I, type II and type III [17,20,21]. Fibronectin type II (FNII) modules can be found in a small number of proteins including matrix metalloproteinase-2 (MMP-2) and matrix metalloproteinase-9 (MMP-9) [22,23]. MMP-2 comprises three tandem gelatin/ collagen-binding FNII domains (Supplementary Fig. S1) in its catalytic domain and all three FNII modules contribute to binding to gelatin/collagen [22,24-27]. Thus, the FNII module from human MMP-2 displays promising characteristics for the improvement of cell adhesion and collagen-binding activity of biomimetic materials, being a promising candidate for functionalization of spider silks with biomedical application purposes

Recombinant production of spider silk proteins has, however, been hampered by its low bioproduction levels, usually in the milligram per liter range $[28,29]$, most likely due to translational and transcriptional limitations [30-32] such as translational pauses during synthesis [33]. Although expression levels up to $1 \mathrm{~g} . \mathrm{L}^{-1}$ have been reported [29], the final yield is significantly decreased during protein purification. The polyalanine region in the silk primary sequence spontaneously self-assembles into crystalline $\beta$-sheets reducing the solubility of spider silks [34,35], therefore restricting the purification process.

Blending spider silk with silk-elastin-like proteins (SELPs) can be a suitable approach for cost-effective manufacture of silk polymers. SELPs are an exceptional family of rPBPs, consisting of alternate amino acid repetitions of silk blocks (GAGAGS) derived from silk fibroin, and elastin blocks (VPGXG, X: any amino acid except for proline) derived from mammalian elastin, repeated in tandem [36]. Within the SELP family, SELP-59-A has been effortlessly expressed and purified with high volumetric productivities (4.3 g.L ${ }^{-1}$ ) [37]. Furthermore, this SELP copolymer has been processed into fibre mats by electrospinning for tissue engineering applications [38] and into free standing films by solvent casting [39], demonstrating its versatility of processing as well as its unique physical, mechanical and biological properties that highlight potential biomedical purposes.

Aiming at creating novel non-cytotoxic biopolymers, the complete FNII module from MMP-2 was explored as a new cell adhesion motif to be used in biomaterials. In this work, a chimeric protein composed of the FNII module and a spider silk block carrying six repeats of the consensus region of MaSp1 (6mer) was produced through genetic engineering in Escherichia coli. In addition, a number of silk-based blends combining this novel polymer with SELP-59-A were produced with the purpose of developing biomaterials for biotechnological applications at a reduced cost while enhancing their biological performance.

\section{Materials and methods}

\subsection{Gene construction}

Genetic constructions were prepared by standard genetic engineering techniques using DNA sequences optimized for E. coli codon usage. All constructs were confirmed by DNA sequencing (Eurofins Genomics).

\subsubsection{6mer + FNII gene}

The pET30L vector carrying the spider silk block (6mer) was prepared as previously described [40]. The plasmid contains a SpeI restriction digestion site at the C-terminus of the 6mer sequence, allowing for the subcloning of functional domains. The nucleotide sequence coding for the FNII module from MMP-2 with flanking SpeI restriction sites was chemically synthesized (GenScript) and cloned into the vector pUC57 (Novagen, San Diego CA). The DNA was digested with SpeI and subcloned into pET30L. The insertion and sequence orientation were confirmed by restriction digestion, followed by DNA sequencing and then transformed into E. coli BL21 (DE3) (Novagen, San Diego CA) and used for production.

\subsubsection{SELP-59-A gene}

The genetic construct for expression of SELP-59-A (56.6 kDa) protein was obtained by seamless cloning as previously described [36]. The complete amino acid composition of SELP-59-A was previously reported [36] and consists of 9 tandem repetitions of S5E9, where $\mathrm{S}$ is the silk block with sequence GAGAGS and $\mathrm{E}$ is the elastin block with sequence VPAVG (Supplementary Fig. S2).

\subsection{Production and purification of SELP-59-A}

Optimal growth conditions for SELP-59-A expression were previously described by our group, either using auto-induction media [36], or by using high-cell density approaches [37,41]. In this study, the SELP-59-A protein was produced in E. coli BL21(DE3) using a fed-batch approach [37] and purified by a non-chromatographic method involving acid-based cell lysis followed by ammonium sulfate purification [36]. Finally, the protein-enriched solution was dialysed and lyophilised. From here on in this publication SELP59-A will be referred to as SELP.

\subsection{Production of $6 \mathrm{mer}+$ FNII}

In an attempt to optimize the production of 6 mer + FNII various previously optimized production approaches were investigated using both batch [36] and fed-batch [37] culture conditions. The highest production was obtained with high cell density culture (dry cell weight of $60 \mathrm{~g} / \mathrm{L}$ ) using $1 \mathrm{mM}$ IPTG induction for $4 \mathrm{~h}$ with pre and post-induction growth rates of $0.4 \mathrm{~h}^{-1}$ and $0.1 \mathrm{~h}^{-1}$, respectively. Sodium dodecyl sulfate-polyacrylamide gel electrophoresis (SDS-PAGE) on a $10 \%$ gel, followed by Coomassie blue staining, was used to analyse and compare productivities in both the soluble and insoluble intracellular fractions.

\subsection{Purification of 6 mer + FNII from inclusion bodies}

Bacterial cell pellets were resuspended in TE buffer solution (50 mM Tris- $\mathrm{HCl}+1 \mathrm{mM}$ EDTA at $\mathrm{pH} 8.0$ ), disrupted by ultrasonic lysis sonication using a Vibra cell ${ }^{\mathrm{TM}} 75043$ (Bioblock Scientific) with a $25 \mathrm{~mm}$ diameter probe ( $3 \mathrm{~s}$ pulse on, $9 \mathrm{~s}$ pulse off, total sonication time: $10 \mathrm{~min}$ ) and centrifuged at $11,500 \times \mathrm{g}$, for $20 \mathrm{~min}$ at $4{ }^{\circ} \mathrm{C}$. The inclusion bodies-enriched pellet was resuspended and washed four times in washing solution $(50 \mathrm{mM}$ Tris- $\mathrm{HCl}, 150 \mathrm{mM} \mathrm{NaCl}, 1 \%$ Triton X-100 and 20\% Sucrose, $\mathrm{pH} 8.0$ ) with centrifugation at $11,500 \times \mathrm{g}$, for $20 \mathrm{~min}$, at $4{ }^{\circ} \mathrm{C}$ to remove contaminants. Purified inclusion bodies were then solubilized in buffer ( $8 \mathrm{M}$ Urea, $100 \mathrm{mM} \mathrm{HNa} 2 \mathrm{PO}_{4}, 10 \mathrm{mM}$ Tris- $\mathrm{HCl}$ at $\mathrm{pH} 8.0$ ), filtered through a $0.45 \mu \mathrm{m}$ filter, and desalted into deionized water with a HiPrep 26/10 desalting column (GE Healthcare) and lyophilised. 


\subsection{Western blot analysis}

Following 10\% SDS-PAGE analysis, protein bands were transferred from the SDS-PAGE gel to a nitrocellulose membrane in a Mini trans-Blot ${ }^{\circledR}$ Cell (Bio-Rad) at $100 \mathrm{~V}$ for $1 \mathrm{~h}$. The membrane was blocked for $1 \mathrm{~h}$ with $5 \%$ non-fat dried milk in TBS-T buffer (50 mM Tris- $\mathrm{HCl}, 150 \mathrm{mM} \mathrm{NaCl}, 0.05 \%$ Tween 20 at pH 8), washed with TBS-T and incubated overnight with mouse monoclonal antipolyHistidine antibody (Sigma-Aldrich) diluted 1:3000 in the blocking solution. Following incubation the membrane was washed with TBS-T and incubated with goat anti-mouse IgG peroxidase (HRP) antibody (Sigma-Aldrich) diluted 1:5000 in the blocking solution. Protein detection was made by chemiluminescence using WesternBright ECL spray (Grisp) and X-ray films were developed with a Curix 60 film processor (AGFA HealthCare).

\subsection{Solvent casting and post-processing treatment of films}

Films of 6mer + FNII, SELP and SELP blended with 6mer + FNII (SELP/6mer + FNII) were prepared by solvent casting using formic acid (98-100\%, Merck) as solvent [39]. 6mer + FNII films were produced by dissolution of the pure lyophilized protein to a final concentration of $10 \%(\mathrm{w} / \mathrm{v})$. SELP films were produced by dissolving the pure lyophilized protein to a final concentration of $3 \%(w / v)$. Silk-based blends were produced by combining SELP with different percentages of $6 \mathrm{mer}+\mathrm{FNII}(5,15$ and $30 \mathrm{wt} \%)$ regarding the amount of SELP. Then, $100 \mu \mathrm{l}$ of each protein solution was cast into a $15 \mathrm{~mm}$ (diameter) polytetrafluoroethylene (PTFE, Teflon ${ }^{\circledR}$ ) surface and allowed to dry at room temperature until complete solvent evaporation. For post-processing treatment, the free standing films were treated with methanol-saturated air at $25^{\circ} \mathrm{C}$ for $48 \mathrm{~h}$ in a vapor chamber [39] and air-dried at room temperature for at least $48 \mathrm{~h}$ before characterization.

\subsection{Fluorescein isothiocyanate (FITC) labelling}

6 mer + FNII was linked to FITC $(100 / 1, w / w)$ in sodium carbonate buffer $\mathrm{pH} 8.5$ for $8 \mathrm{~h}$ at $4{ }^{\circ} \mathrm{C}$ in dark conditions. Free FITC was removed by sequential washing steps and monitored by measuring the absorbance in the range of 300-600 nm (FITC absorption maximum $=495 \mathrm{~nm}$ ) in a UV-1700 PharmaSpec Shimadzu spectrophotometer. Blend films of FITC-labelled 6mer + FNII and SELP were produced using the methodology described above (Section 2.6). The distribution of 6 mer + FNII within the SELP matrix was analysed on a Leica DM-5000B epifluorescence microscope with appropriate filter settings. Three random images for each sample were acquired with a Leica DCF350FX digital camera and processed with LAS AF Leica software.

\subsection{Mechanical characterization}

Uniaxial tensile failure measurements were carried out at ambient conditions $\left(\sim 25^{\circ} \mathrm{C}\right)$ with a Shimadzu Universal Testing Machine (AG-IS with a load cell of $50 \mathrm{~N}$ ) with a defined strain rate of $0.5 \mathrm{~mm} / \mathrm{min}$. The ultimate tensile strength (UTS), the strain-tofailure $(\varepsilon)$ and the modulus of elasticity (E) were determined, with the latter being calculated in the linear zone of elasticity, between 0 and $1 \%$ of strain, for all samples.

\subsection{Attenuated total reflection-fourier transform infrared analysis (ATR-FTIR)}

FTIR spectra from $4000 \mathrm{~cm}^{-1}$ to $600 \mathrm{~cm}^{-1}$ were acquired at room temperature with a Spectrum Two spectrometer from Perkin Elmer in ATR mode. FTIR spectra were collected after 64 scans with a resolution of $4 \mathrm{~cm}^{-1}$ followed by ATR correction using the man- ufacturer's software (Spectrum 10, Perkin Elmer). Atmospheric $\mathrm{CO}_{2} / \mathrm{H}_{2} \mathrm{O}$ was automatically corrected during spectra collection using theoretical water vapor and carbon dioxide spectra. Quantification of the secondary structure was based on the analysis of the amide I region $\left(1700-1600 \mathrm{~cm}^{-1}\right)$ by second derivatization and Gaussian curve fitting [39,42-45] using OriginPro 9.0 software (OriginLab, Northampton, MA). Derivatization analysis can be used to separate overlapping bands and can be performed objectively without choosing arbitrary deconvolutional parameters [45]. The original spectral data (non-smoothed) in the amide I region was truncated and normalized, followed by linear baseline correction. For component analysis, the second-derivative spectra of the amide I region were smoothed with an eleven-point SavitskyGolay smoothing function. As the data was collected with an interval of $1 \mathrm{~cm}^{-1}$, the selection of eleven-point windows covers a $11 \mathrm{~cm}^{-1}$ spectral region which is less than the half width at half maximum for almost all amide I band components [45]. The number of components and their peak positions were determined by second derivatization and used as starting parameters for curvefitting iteratively with a Gaussian function using the LevenbergMarquardt algorithm $[43,45,46]$. To make the secondary structure assignment comparable between all the samples, curve fitting was performed with the same set of parameters. During fitting, the amplitude of components were allowed to vary freely but the frequency and bandwidth were constrained to a $2 \mathrm{~cm}^{-1}$ variation. A Gaussian function was used over Lorentzian band shape as it gave the best fit with a coefficient of determination $\left(R^{2}\right)$ higher than 0.99 for all the spectra. Fitting quality was also evaluated by examination of residuals between the original and the fitted curve. Secondary structure composition was estimated from the relative area of the single bands assigned to the different structures assuming that the extinction coefficient for the $\mathrm{C}=0$ stretch vibration is the same for the different structural components $[47,48]$. The contribution of each fitted component to the amide I band was thus determined by integration of the area under the curve and normalizing for the total area of amide I. The absorbance values of methanol-treated SELP and methanol-treated SELP/6mer + FNII blend films were comparable to those obtained with untreated films.

\subsection{In vitro cytotoxicity evaluation of films}

In vitro cytotoxicity evaluation was assessed with telomeraseimmortalized normal human skin fibroblasts cell line (BJ-5ta) obtained from the American Type Culture Collection (ATCC). Cells were cultured according to ATCC recommendations in complete medium (4 parts Dulbecco's modified Eagle's medium containing $4 \mathrm{mM}$ L-glutamine, 4.5 g.L $\mathrm{L}^{-1}$ glucose, 1.5 g.L $\mathrm{L}^{-1}$ sodium bicarbonate and 1 part Medium 199) supplemented with $10 \%(\mathrm{v} / \mathrm{v})$ fetal bovine serum (FBS), 1\% (v/v) penicillin/streptomycin and $10 \mu \mathrm{g} \cdot \mathrm{mL}^{-1}$ hygromycin $\mathrm{B}$ at $37^{\circ} \mathrm{C}$ with $5 \% \mathrm{CO}_{2}$ in a humidified environment. Short term cell viability in response to the methanol-treated films was assessed by indirect contact using the MTT (3-(4,5-dimethyl thiazol-2-yl)-2,5-diphenyltetrazolium bromide) assay according to the manufacturer's (Sigma-Aldrich) instructions. 6mer + FNII and SELP/6mer + FNII films were sterilized with $1 \%(\mathrm{v} / \mathrm{v})$ penicillin/streptomycin $(3 \times 20 \mathrm{~min})$, washed with sterile phosphatebuffered saline solution (PBS; $137 \mathrm{mM} \mathrm{NaCl}, 2.7 \mathrm{mM} \mathrm{KCl}, 10 \mathrm{mM}$ $\mathrm{Na}_{2} \mathrm{HPO}_{4}, 1.8 \mathrm{mM} \mathrm{KH} \mathrm{PO}_{4}$ at $\mathrm{pH} 7.4$ ) and incubated with $1 \mathrm{~mL}$ of cell culture medium for $24 \mathrm{~h}$ at $37^{\circ} \mathrm{C}$ with $5 \% \mathrm{CO}_{2}$ in a humidified environment. In parallel, a suspension of $1 \times 104 \mathrm{BJ}-5$ ta cells. $\mathrm{mL}^{-1}$ was seeded in surface treated 24-well plates (Nunclon polystyrene 24-well MicroWell, Thermo Scientific) for $24 \mathrm{~h}$ under the conditions described above. Following incubation the cell culture medium was removed and replaced with the medium conditioned by the $24 \mathrm{~h}$ contact with the films. Cell viability was then evaluated 
after $24 \mathrm{~h}$ using the MTT proliferation assay. SELP films were used as controls for the assay wherein cells cultured in standard culture medium and in 30\% DMSO (Sigma-Aldrich) were used as positive and negative controls, respectively. Results were expressed as percentage of viability in relation to the positive control (set as $100 \%$ viability).

\subsection{Cell adhesion}

Previously sterilized films were transferred to sterile 24-well plates and BJ-5ta cells were seeded at a density of $1 \times 104$ cells per well and incubated for 12, 24 and $48 \mathrm{~h}$ on the different film surfaces. For immunofluorescence microscopy, cells were fixed with $3.7 \%$ formaldehyde (Merck) in PBS for $10 \mathrm{~min}$, washed with PBS and permeabilized in $0.1 \%$ TritonX-100 in PBS for 5 min. Cells were then washed with PBS and incubated with phalloidin (Alexa Fluor ${ }^{\circledR}$ 594 phalloidin, Life Technologies ${ }^{\mathrm{TM}}$ ) in the dark for $20 \mathrm{~min}$. Afterwards, cells were washed with PBS and cell morphology and spreading was observed using a fluorescence microscope (Olympus IX71 inverted microscope) with photos from random locations being digitally recorded and compared. Cell adhesion was further assessed by scanning electron microscopy (SEM) for a detailed visualization of cell-material interactions. For SEM analysis, samples were soaked in a fixation solution $(1 \mathrm{~mL}$ of $2.5 \%$ glutaraldehyde (Merck) in PBS) for $1 \mathrm{~h}$ at room temperature, rinsed with distilled water and dehydrated by immersion for $30 \mathrm{~min}$ in a series of successive ethanol-water solutions (55\%, 70\%, 80\%, 90\%, 95\% and $100 \% \mathrm{v} / \mathrm{v}$ of ethanol). The samples were then dried at room temperature and coated with a thin gold layer using a sputter coater
(Fision Instruments, Polaron Sputter Coater SC502) prior to SEM analysis (Leica Cambridge S360, UK) with an accelerating voltage of $20 \mathrm{kV}$.

\subsection{Statistical analysis}

One-way analysis of variance (ANOVA) with Bonferroni's posttest was carried out using GraphPad Prism 6 software to compare the means of the different data sets within each experiment. A value of $\mathrm{p}<0.05$ was considered to be statistically significant. All experiments were performed in triplicate.

\section{Results and discussion}

\subsection{Expression of 6mer + FNII}

The chemically synthesized FNII coding sequence was successfully ligated in frame to the $3^{\prime}$ end of the 6mer spider silk-based gene in the vector pET30L [40] via the Spel restriction site (Fig. 1). This construct (pET30L::6mer + FNII) was then transformed into E. coli BL21(DE3) for subsequent protein production studies. Production of rPBPs often constitutes a major bottleneck for development but in this work 6mer + FNII was efficiently produced with the approaches investigated. The protein accumulated as inclusion bodies in the intracellular insoluble fraction (Fig. 2A). Attempts were made to produce soluble 6mer + FNII [49], namely by lowering the fermentation temperature (to $18^{\circ} \mathrm{C}$ ) and by coexpression with chaperones induced by incubation for $30 \mathrm{~min}$ on ice in the presence of $2 \%$ ethanol, but without success (not shown).

\section{MHHHHHHSSGLVPRGSGMKETAAAKFERQHMDSPDLGTDDDDKAMAASGRGGLGGQGAGAAAAAGGAGQGGYGGLGSQGTSGR \\ GGLGGQGAGAAAAAGGAGQGGYGGLGSQGTSGRGGLGGQGAGAAAAAGGAGQGGYGGLGSQGTSGRGGLGGQGAGAAAAAGGA \\ GQGGYGGLGSQGTSGRGGLGGQGAGAAAAAGGAGQGGYGGLGSQGTSGRGGLGGQGAGAAAAAGGAGQGGYGGLGSQGTSRVKY \\ GNADGEYCKFPFLFNGKEYNSCTDTGRSDGFLWCSTTYNFEKDGKYGFCPHEALFTMGGNAEGQPCKFPFRFQGTSYDSCTTEGRTDGYR \\ WCGTTEDYDRDKKYGFCPETAMSTVGGNSEGAPCVFPFTFLGNKYESCTSAGRSDGKMWCATTANYDDDRKWGFCPDQGYSTSSTOp}

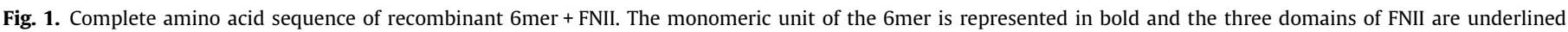
(structure and amino acid sequence of FNII is further detailed in the Supplementary data, Fig. S1).

(a)

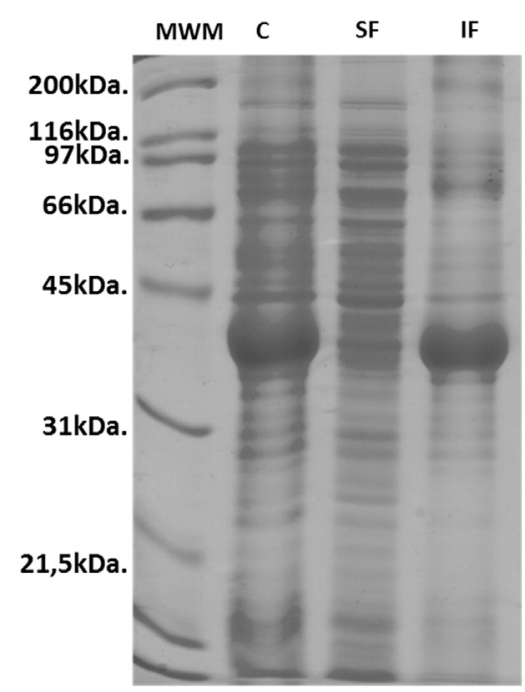

(b)

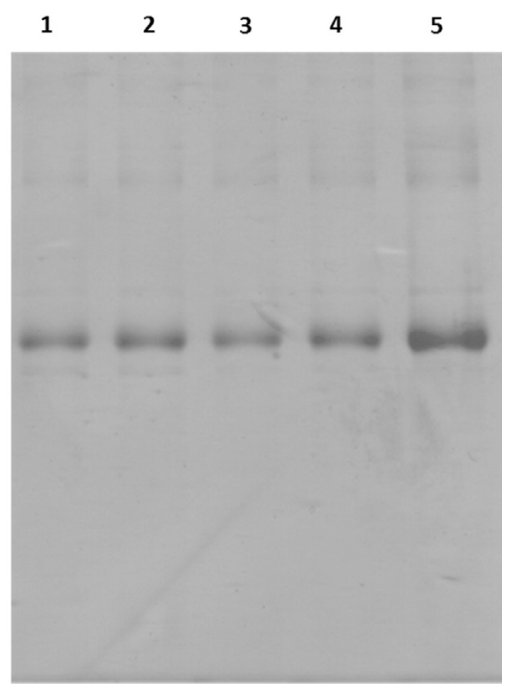

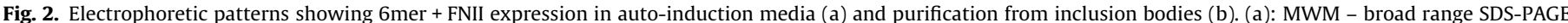

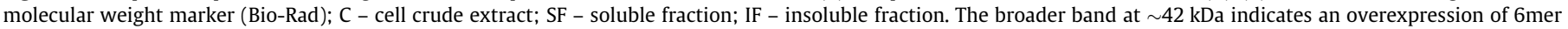
+ FNII with accumulation in the insoluble fraction. (b): Lanes 1-4 - washing steps. Lane 5 - solubilization of inclusion bodies in urea buffer solution. 
(a)

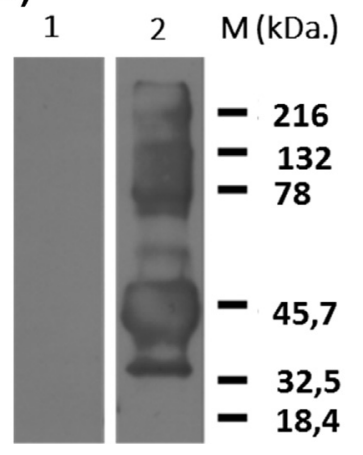

(b)

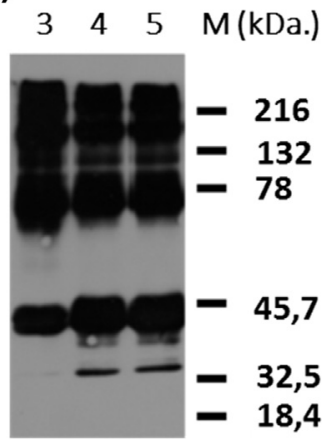

Fig. 3. Western Blot analysis of (a) cell crude extracts and (b) purified fraction of 6 mer + FNII without and with the addition of reducing agents. (a): lane 1 - cell crude extract of untransformed $E$. coli; lane 2 - cell crude extract of $E$. coli cell cultures expressing 6 mer + FNII. (b): lane 3 - non-reduced $6 \mathrm{mer}+$ FNII; lane 4$6 \mathrm{mer}+\mathrm{FNII}+1 \mathrm{mM}$ DTT; lane 5-6mer + FNII + $10 \mathrm{mM} \quad \beta$-mercaptoethanol. The presence of several bands at higher molecular weights indicates various degrees of multimerization (monomeric protein $\sim 42 \mathrm{kDa}$ ). These multimers are very stable and do not disassemble with the addition of reducing agents. The bands observed at a molecular weight lower than $42 \mathrm{kDa}$ are most likely due to truncated forms of 6 mer + FNII. MWM - broad range Kaleidoscope ${ }^{\mathrm{TM}}$ SDS-PAGE (Bio-Rad).

6 mer + FNII production by auto-induction $[36,50]$ in batch fermentation resulted in volumetric productivities, quantified after purification, of approximately $180-200 \mathrm{mg} \cdot \mathrm{L}^{-1}$. This is about 10 -fold higher than that previously reported for other functionalized spider silk 6mer-based proteins [10,51-53] and similar to the quantities of SELPs produced using this approach [36]. In addition, similar to that previously reported, a 10-fold [37] increase in biomass was achieved with a fed-batch fermentation process which allowed for a corresponding increase in polymer productivity to $\mathrm{g} / \mathrm{L}$ quantities (data not shown). While this latter process is technically more challenging and labor intensive than the other approaches, the high productivities attained here point to the potential of $6 \mathrm{mer}$ + FNII for the development of future applications.

\subsection{Purification of $6 m e r+F N I I$}

As 6mer + FNII accumulated in inclusion bodies (Fig. 2A) these were purified from the cell lysate and cellular debris by successive washing and centrifugation steps, followed by solubilization in $8 \mathrm{M}$ urea, desalting and drying by lyophilisation (Fig. 2B). SDS-PAGE analysis revealed the presence of a strong band at the expected size ( $\sim 42 \mathrm{kDa}$ ) but with other higher molecular weight bands also visible. Western blot analysis using anti-polyHistidine antibodies (Fig. 3A) demonstrated that all bands showed reactivity, thereby indicating the presence of 6 mer + FNII multimers and breakdown products. Indeed, this multimerization of 6 mer and 6 mer chimeric proteins has been observed in previous studies and are reported as being the consequence of monomer aggregation and preterminated products $[5,10,51-53]$. This outcome might be due to the polyalanine blocks of the 6 mer silk domain forming a highly hydrophobic core leading to aggregation and precipitation above a critical concentration [10]. On the other hand, 6mer + FNII oligomerization can also be disulfide bond-mediated, since each of the three FNII modules comprises four cysteine residues involved in disulfide bridges [54]. Considering this feature, two different reducing agents, dithiothreitol (DTT) and $\beta$ mercaptoethanol, were added to the purified protein fraction. However, the multimers were stable to the reducing agents (Fig. 3B) further suggesting that the higher molecular weight bands are likely due to 6mer + FNII aggregation mediated through hydrogen-bonding between the alanine residues of the silk block.

\subsection{Structural analysis by ATR-FTIR}

Films were prepared following dissolution in formic acid by casting on PTFE Teflon moulds with evaporation at room temperature. Formic acid has been previously used as solvent in the fabrication of silk fibroin films, yielding a transparent and stable solution [39] and here transparent free standing films were obtained in all cases. As-cast SELP cast films readily dissolved after a few minutes in contact with water [39] thereby limiting potential applications, in particular where the films are in contact with an aqueous environments such as culture media or body fluids. Treatment with methanol circumvents this limitation, rendering aqueous insolubility by promoting the formation of insoluble $\beta$-sheet structures that maintain the SELP films structural integrity $[38,39,48,55,56]$. For this reason, the films were exposed to methanol-saturated air to render aqueous insolubility and change the secondary structure as assessed by FTIR spectroscopy. Secondary structure analysis was performed in the amide I region (1600$1700 \mathrm{~cm}^{-1}$ ) which originates from the $\mathrm{C}=0$ stretching vibration of the amide group coupled with the in-phase bending of the $\mathrm{N}-\mathrm{H}$ bond and out-of-phase C-N stretching vibrations [57-59], corresponding to the most sensitive spectral region used for protein studies. This region is sensitive to small variations in molecular geometry and hydrogen bonding and therefore gives valuable information about the secondary structure and conformational changes of proteins $[45,60]$. Before the methanol treatment, the IR spectrum of all samples was characterized by an amide I absorption band centered around $1625 \mathrm{~cm}^{-1}$ which is attributed to an antiparallel $\beta$-sheet conformation [35,48] (Fig. 4A). Moreover, a pronounced shoulder at $1645 \mathrm{~cm}^{-1}$ attributed to random coils/ extended chains [48] was also observed (Fig. 4A). The broadness of the amide I band indicates the presence of other conformations however, the peak center located around $1625 \mathrm{~cm}^{-1}$ suggests that the secondary structure is dominated by $\beta$-sheets with a relevant contribution arising from other structures. In all films, after the methanol treatment, the amide I band was narrower and shifted to $1622 \mathrm{~cm}^{-1}$, suggesting that major contributions arise from $\beta$ structures and less from other secondary structures. This behavior was previously observed for SELP films [39] and fibres [38] in which the amide I band shifted to lower wavenumbers after the methanol treatment.

Although the amide I band is useful for the analysis of protein conformation, it is usually a single broad band with overlapping components that arises from various secondary structure elements [61] Band-narrowing or resolution enhancement techniques such as second derivative analysis provide a more detailed characterization of protein conformation by providing a basis for the quantitative estimation of protein secondary structure [45,62,63]. Despite the limitations and drawbacks associated to the technique $[57,60,64,65]$ resolution enhancement and curve fitting analysis can represent a valuable tool to compare the secondary structure content of samples in different conditions, considering that all the parameters for fitting and band narrowing are maintained.

To study the secondary structure composition in more detail and especially to assess the evolution of the $\beta$-structure content after the methanol-treatment, second derivative analysis and curve fitting methods were employed in the amide I band region of the FTIR spectra (Fig. 4B). For each fitted band, a structural conformation was assigned by reference to the literature (Supplementary Table S1). The $\beta$-structure content of the SELP films was higher than that observed for the blend films reaching values of $\sim 52 \%$ and $\sim 60 \%$ for the non-treated and methanol-treated films, respectively (Fig. 4C). In comparison, the $\beta$-structure content in the nontreated blend films was of approximately $40 \%$, increasing to $~ 52 \%$ after exposure to methanol. This clearly indicates that methanol induces a molecular reorganization leading to the formation of 
A

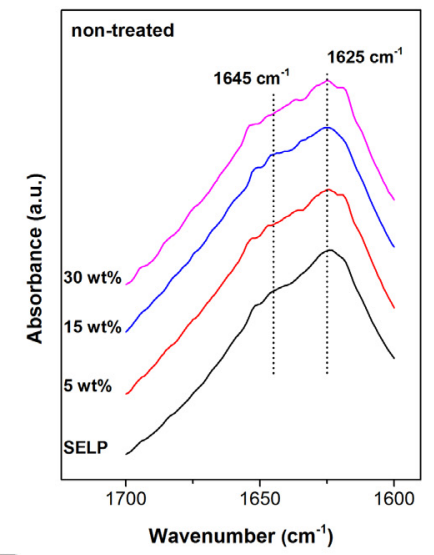

B

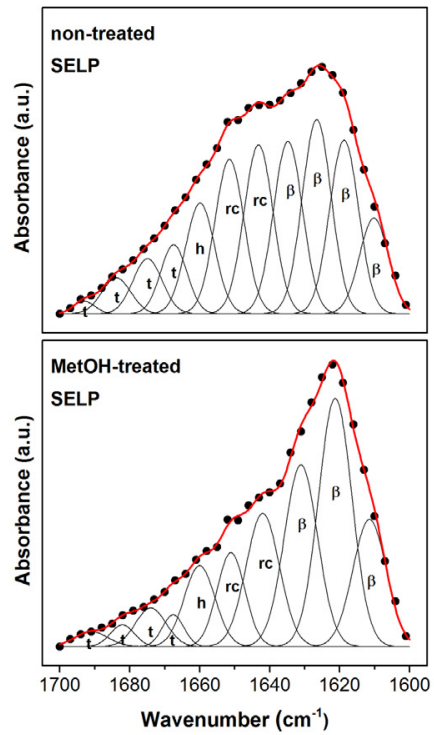

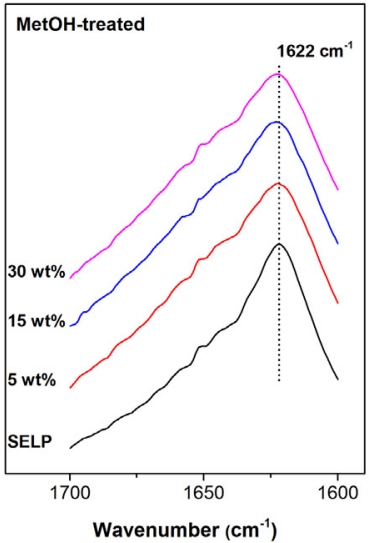
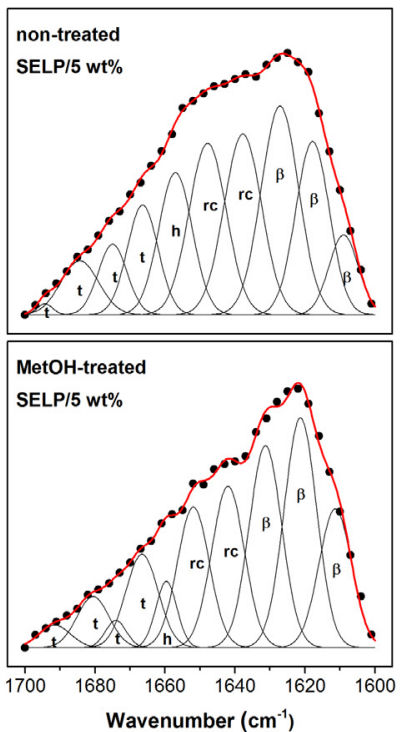

C
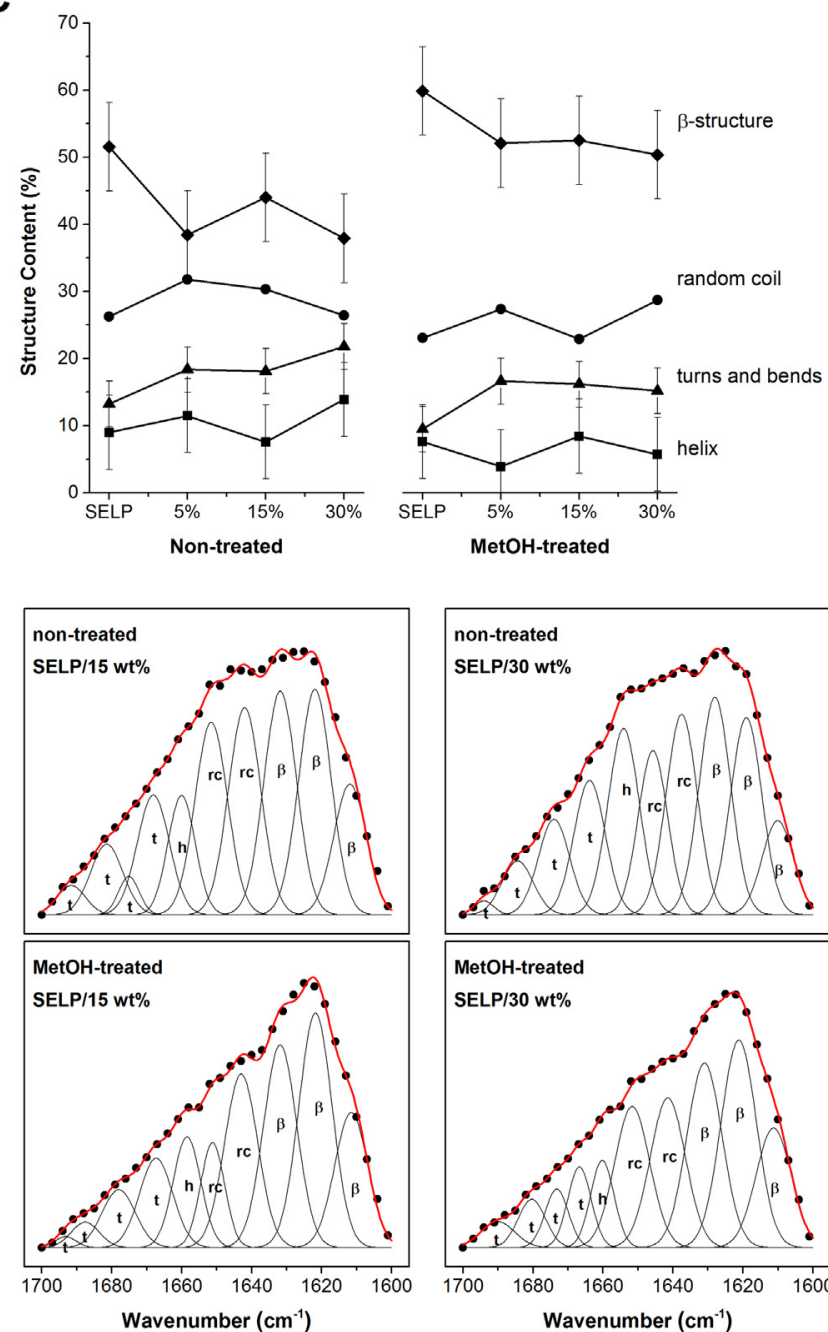
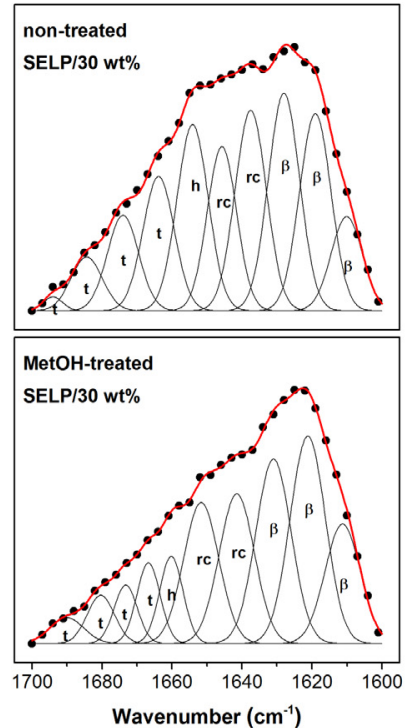

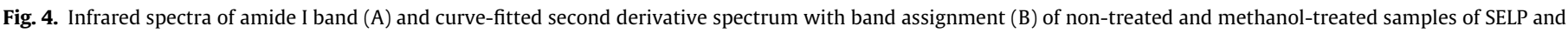

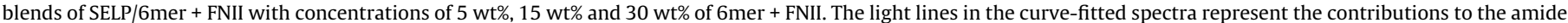

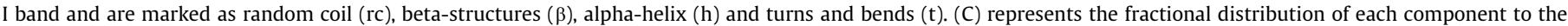

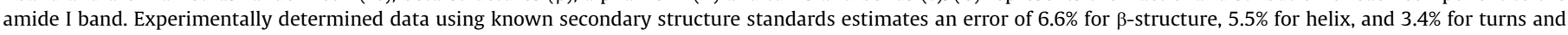
bends [86].

extensively hydrogen-bonded stable $\beta$-structures that likely provide more robust physical cross-links and result in water insolubility $[39,55]$.

\subsection{In vitro cytotoxicity and cell adhesion}

An important aspect to be taken into account when developing polymers for biomedical applications is the absence of cytotoxicity. Viability of normal human skin fibroblasts cell line (BJ-5ta) in response to the films was assessed in vitro by indirect contact using the colorimetric MTT assay. In this assay, metabolically active cells reduce tetrazolium salts into a formazan dye insoluble in tissue culture medium and the amount of formazan dye formed, which can be spectrophotometrically measured at $490 \mathrm{~nm}$, is directly related to the number of living cells in culture. Results of the exposure of BJ-5ta cells to the leachates of the polymeric films revealed no statistically significant cytotoxicity $(\mathrm{p}<0.05)$ (Fig. 5). Similar metabolic activity of cells in contact with pre-conditioned medium and cells cultured in standard medium indicates that putative leached components from the films in solution, if existing, are non-toxic.

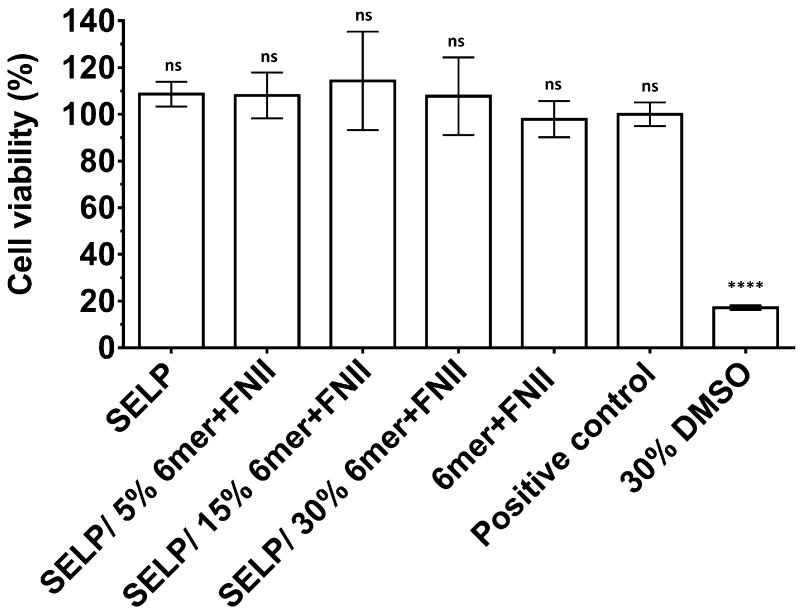

Fig. 5. Viability of BJ-5ta cells cultured on SELP, 6mer + FNII and SELP/FNII + 6mer with different concentrations determined by the MTT assay. Results are represented as \% cell viability in relation to cells cultured in standard medium (positive control). Bars represent means \pm SD (ns - non significant, ${ }^{* * * *} \mathrm{p} \leqslant 0.0001$ ). 


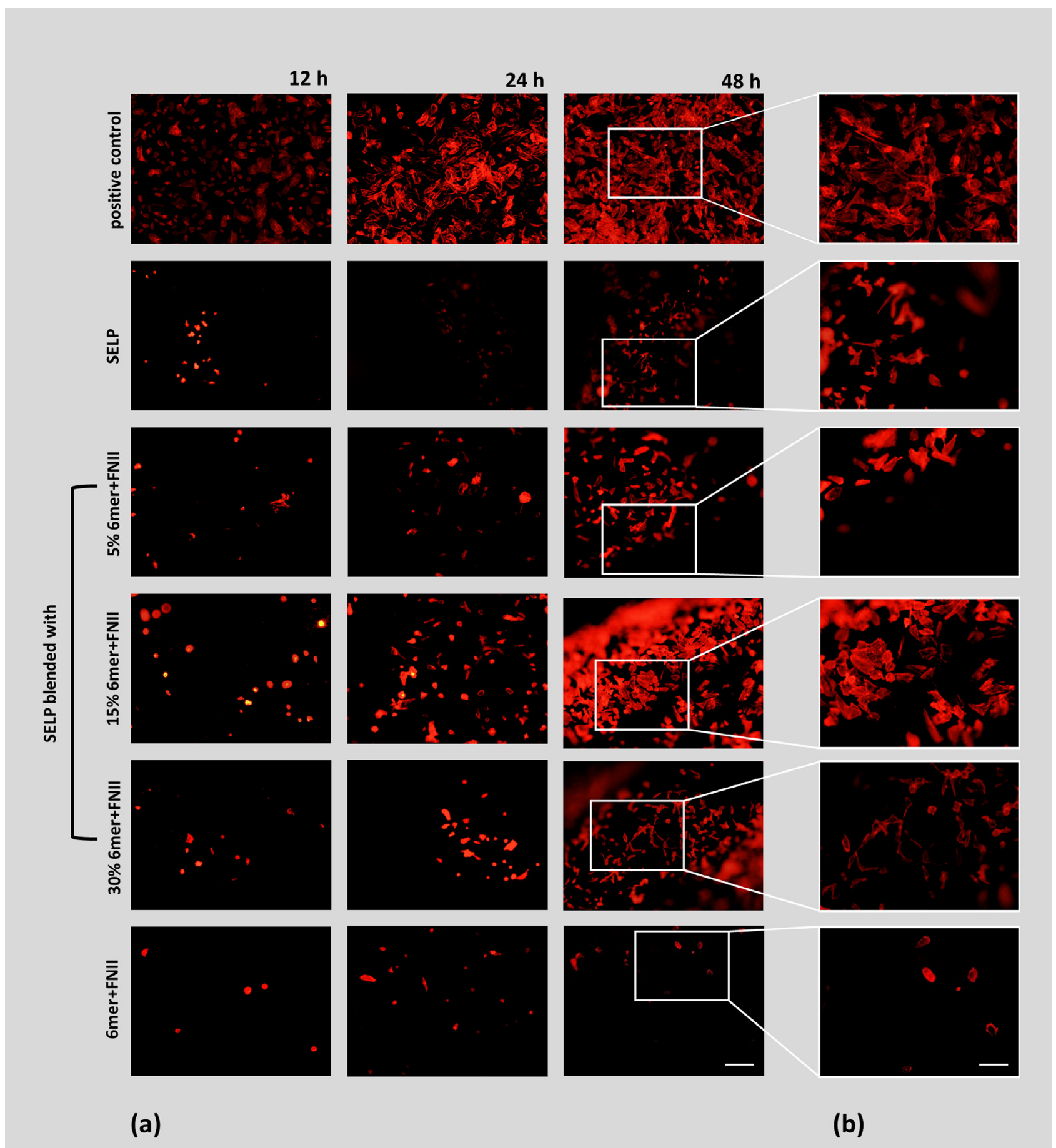

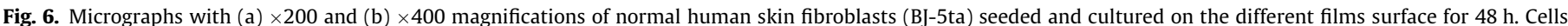

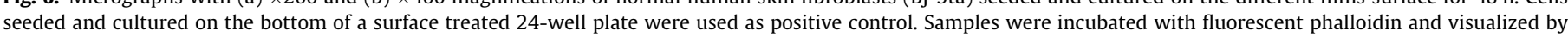
fluorescence microscopy. Scale bars represent $100 \mu \mathrm{m}$ for $\times 200$ magnifications and $50 \mu \mathrm{m}$ for $\times 400$ magnifications.

To evaluate the ability of the films to promote cell adhesion, BJ-5ta cells were cultured on the surface of the films for 12,24 and $48 \mathrm{~h}$. As a positive control, cells were cultured on surface treated wells. Qualitative evaluation of BJ-5ta adhesion was performed by immunofluorescence analysis using fluorescent phalloidin, which binds to filamentous actin (F-actin) and, interestingly, scarce cell adhesion was observed for the neat 6 mer + FNII films (Fig. 6). This result, however, might not be unexpected as it is believed that the amount and distribution of adhesion domains surfaces affect cell adhesion. Several studies have reported that cell adhesion is affected by the density and spatial distribution of RGD, the tripep- tide cell adhesion motif found in fibronectin and other extracellular matrix proteins [66-70]. To overcome this limitation, we investigated the potential of developing a novel biomaterial combining $6 \mathrm{mer}+$ FNII with SELP. Here, it was postulated that the 6 mer + FNII would be homogenously distributed in the SELP matrix and its content would influence cell adhesion. The distribution of 6 mer + FNII in the blend films was assessed via FITC labelling and indeed, the blend films produced with FITC-labelled 6mer + FNII demonstrated an evenly distribution of $6 \mathrm{mer}+$ FNII without any evidences of clustered zones (Supplementary Fig. S3). As demonstrated by the micrographs in Fig. 6, SELP with 6mer + FNII induces 

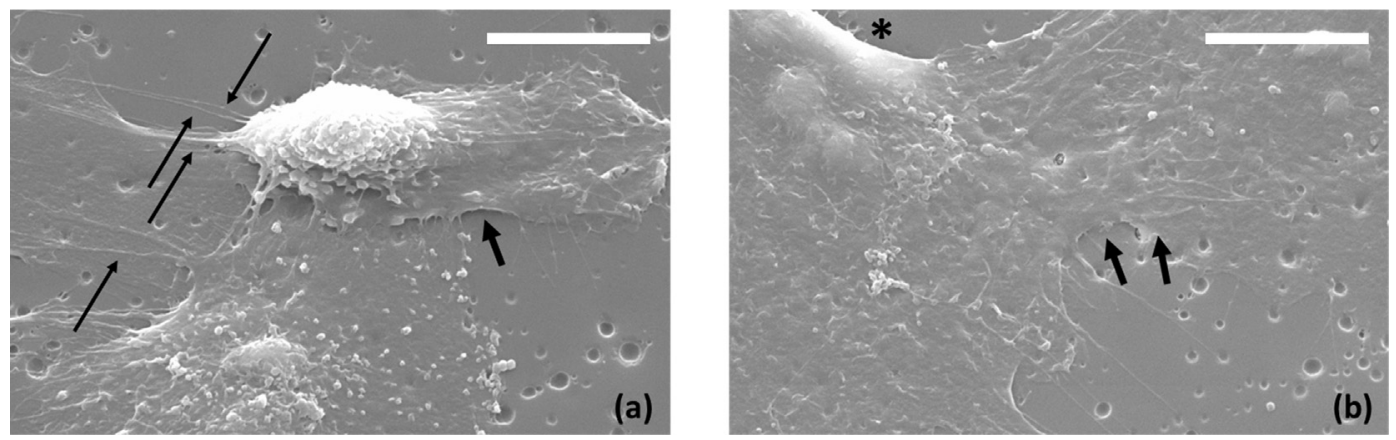

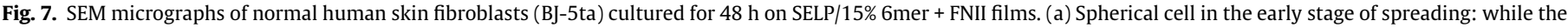

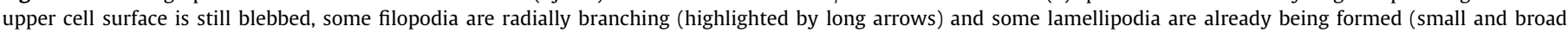
arrow). (b) Already flattened cell (marked by the star) spreading with an enclosing lamellipodium (highlighted by the broad arrows). Scale bars represent $10 \mu \mathrm{m}$.

Table 1

Mechanical properties of methanol-treated SELP and SELP/15\% 6mer + FNII films. E modulus of elasticity; UTS - ultimate tensile strength; $\varepsilon$ - strain-to-failure.

\begin{tabular}{llll}
\hline & $\begin{array}{l}E \pm \text { StdDev } \\
{[\text { GPa] }}\end{array}$ & $\begin{array}{l}\text { UTS } \pm \text { StdDev } \\
{[\mathrm{MPa}]}\end{array}$ & $\begin{array}{l}\varepsilon \pm \text { StdDev } \\
{[\%]}\end{array}$ \\
\hline $\begin{array}{l}\text { Methanol-treated SELP } \\
\text { Methanol-treated SELP/15\% }\end{array}$ & $1.8 \pm 0.5$ & $76.9 \pm 3.5$ & $14.3 \pm 4.8$ \\
6mer + FNII & $1.9 \pm 0.4$ & $71.9 \pm 13.9$ & $11.6 \pm 4.5$ \\
\hline
\end{tabular}

higher adhesion of fibroblasts to films, especially for SELP/15\% 6mer + FNII films. Reduced cell adhesion was observed at a higher content of FNII (SELP/30\% 6mer + FNII), possibly due to a high FNII density (as discussed above) and at a lower content (SELP/5\% 6mer + FNII), probably as a consequence of insufficient FNII domains. In fact, SELP/15\% 6 mer + FNII films showed the greatest cell adhesion for any culture time point as well as a higher number of fibroblasts adhered to the film when compared with the positive control. These results highlight the potential of these proteins for biomaterial applications. Higher magnification micrographs (Fig. 6B) further support this observation, as the prominent cytoskeleton structures known to contain actin microfilaments that form integrin-mediated contact with adjacent cells, extracellular matrix and other substrates, can be clearly seen $[71,72]$.

Cell adhesion and spreading onto substrates involves cell attachment, centrifugal growth of filopodia, cytoplasmic webbing, lamellipodia formation, flattening of the cell and ruffling of the cytoplasm [73]. Representative SEM micrographs of BJ-5ta cells adhered to the SELP/15\% 6mer + FNII films were taken to better examine the cell-substrate interaction. Fig. 7A shows a roughly round-shaped cell adhered to the film in the early stage of spreading and with radial filopodia protruding (highlighted by the long arrows). The radial projection of these actin and integrin-rich filopodial extensions has been reported to have substrateexploring functions being responsible for the initial cell-matrix contact $[74,75]$. On two-dimensional surfaces, these transient filopodia are known to quickly disappear in favor of a lamellipodia-mediated spreading of the cells as it can be seen in Fig. 7B. These results confirm that fibroblasts interact and adhere properly onto the SELP $/ 15 \%$ 6mer + FNII films, which are able to support cell adhesion and proliferation of normal human fibroblasts. Cell-substrate interactions with the remaining films further confirmed that SELP/15\% 6mer + FNII films are better fitted to support fibroblast adhesion and proliferation (Supplementary Fig. S4).

\subsection{Mechanical properties}

The mechanical properties of SELP/15\% 6mer + FNII were assessed under uniaxial tensile strength analysis, demonstrating that there were no significant differences attributed to the 6mer + FNII content (Supplementary Fig. S5). The methanol-treated SELP/15\% 6mer + FNII films revealed an average modulus of elasticity of $1.9 \pm 0.4 \mathrm{GPa}$, an average ultimate tensile strength of $71.9 \pm 13.9 \mathrm{MPa}$ and an average strain-to-failure of $11.6 \pm 4.5 \%$. These values do not differ significantly from those obtained for the methanol-treated SELP films in which the modulus of elasticity, ultimate tensile strength and strain-to-failure were of $1.8 \pm 0.5 \mathrm{GPa}$, $76.9 \pm 3.5 \mathrm{MPa}$ and $14.3 \pm 4.8 \%$, respectively (Table 1 ).

The stress-strain curves were similar for both samples, showing a linear stress-strain relationship up to the yield point, followed by a post-yield plateau and strain-hardening (Supplementary Fig. S5). This behavior was previously observed for other silk-based proteins and attributed to a series of events involving unfolding, breaking of weak intramolecular hydrogen bonds, and alignment of protein chains and stretching of protein backbones and molecular network [76-78]. Interestingly, although displaying comparable mechanical values, this stress-strain profile found for the formic acid-based SELP films was not found when water was used as solvent as previously reported by our group [39]. Furthermore, we must point out that in this work we used different experimental conditions (e.g. solvent, atmospheric humidity, strain rate) that may play a role in the molecular organization of the protein chains, leading to a different mechanical behavior.

\section{Conclusions}

Advances in recombinant DNA technology and protein engineering allow for the design and production of fine-tuned protein-based materials. Due to biocompatibility, mechanical properties and processing versatility, silk-based recombinant materials are attractive for biomedical applications. Synthetic protein biotechnology approaches allow the tailoring of the molecular structure of rPBPs with precise control over sequence and the incorporation of biologically active functionalities [79,80]. This opens up an unprecedented possibility to customize novel materials for specific applications [81]. In this work, we designed and produced a silk-based blended material with cell adhesion properties. All three domains of the fibronectin type II (FNII) module from human matrix metalloproteinase-2 (MMP-2) were exploited for the functionalization of protein-based polymers (PBPs). By genetic engineering the FNII domain was fused with a spider-silk-based polypeptide $(6 \mathrm{mer})$ creating the chimeric protein $6 \mathrm{mer}+\mathrm{FNII}$. Regardless the difficulties allied to the expression and purification of spider silk proteins, the production of the functionalized chimeric protein 6 mer + FNII was successfully optimized and attained, with yields 10-times higher than those previously reported for other functionalized 6mer-based spider silk proteins. For 
biotechnological purposes, blends of $6 \mathrm{mer}+\mathrm{FNII}$ and the silkelastin-like protein SELP-59-A were formulated and efficiently processed into free-standing films by solvent casting. The blend materials revealed mechanical properties comparable to other biopolymers such as PLA [82], blend films of fibroin with humanlike recombinant collagen [83] and recombinant spider silk films $[84,85]$. Cytotoxicity evaluation of these films revealed no cytotoxicity with normal human skin fibroblasts cell line and promoted cell adhesion. A critical percentage of $6 \mathrm{mer}+$ FNII was found. The present study outlines the formulation of new biocompatible silk-based blends with cell adhesion properties able to support cell proliferation. Furthermore, this biomaterial provides a platform for the creation of novel biomaterials including hydrogels and fibre mats suitable for biomedical applications in regenerative medicine.

\section{Acknowledgements}

This work was supported by Fundação para a Ciência e Tecnologia (FCT - Portugal) Funded Project "Chimera" (PTDC/EBBEBI/109093/2008), by FCT/MEC through Portuguese funds (PIDDAC) - PEst-OE/BIA/UI4050/2014, by the strategic programme UID/ BIA/04050/2013 (POCI-01-0145-FEDER-007569) funded by national funds through the FCT I.P. and by the ERDF through COMPETE2020 - Programa Operacional Competitividade e Internacionali zação (POCI). TC is thankful to the FCT, ESF and POPH for its support through the Investigador FCT Programme (IF/01635/2014). ARibeiro thanks FCT for the SFRH $\backslash$ BPD $\backslash 98388 \backslash 2013$ grant. AMPereira, RMachado and AdaCosta acknowledge FCT for PD/BD/113811/2015, SFRH-BPD/86470/2012 and SFRH/BD/75882/2011 grants, respectively.

\section{Appendix A. Supplementary data}

Supplementary data associated with this article can be found, in the online version, at http://dx.doi.org/10.1016/j.actbio.2016.10. 002.

\section{References}

[1] D. Chow, M.L. Nunalee, D.W. Lim, A.J. Simnick, A. Chilkoti, Peptide-based biopolymers in biomedicine and biotechnology, Mater. Sci. Eng. R Rep. 62 (2008) 125-155.

[2] S. Gomes, I.B. Leonor, J.F. Mano, R.L. Reis, D.L. Kaplan, Natural and genetically engineered proteins for tissue engineering, Prog. Polym. Sci. 37 (2012) 1-17.

[3] J.G. Hardy, L.M. Römer, T.R. Scheibel, Polymeric materials based on silk proteins, Polymer 49 (2008) 4309-4327.

[4] C. Vepari, D.L. Kaplan, Silk as a biomaterial, Prog. Polym. Sci. 32 (2007) $991-$ 1007.

[5] S. Gomes, J. Gallego-Llamas, I.B. Leonor, J.F. Mano, R.L. Reis, D.L. Kaplan, In vivo biological responses to silk proteins functionalized with bone sialoprotein, Macromol. Biosci. 13 (2013) 444-454.

[6] M.B. Hinman, R.V. Lewis, Isolation of a clone encoding a second dragline silk fibroin. Nephila clavipes dragline silk is a two-protein fiber, J. Biol. Chem. 267 (1992) 19320-19324.

[7] T. Scheibel, Spider silks: recombinant synthesis, assembly, spinning, and engineering of synthetic proteins, Microb. Cell Fact. 3 (2004). 14-14.

[8] T. Asakura, M. Isozaki, T. Saotome, K.-I. Tatematsu, H. Sezutsu, N. Kuwabara, Y. Nakazawa, Recombinant silk fibroin incorporated cell-adhesive sequences produced by transgenic silkworm as a possible candidate for use in vascular graft, J. Mater. Chem. B 2 (2014) 7375-7383.

[9] E. Bini, C.W.P. Foo, J. Huang, V. Karageorgiou, B. Kitchel, D.L. Kaplan, RGDfunctionalized bioengineered spider dragline silk biomaterial, Biomacromolecules 7 (2006) 3139-3145.

[10] S.C. Gomes, I.B. Leonor, J.F. Mano, R.L. Reis, D.L. Kaplan, Antimicrobial functionalized genetically engineered spider silk, Biomaterials 32 (2011) 4255-4266.

[11] J. Huang, C. Wong, A. George, D.L. Kaplan, The effect of genetically engineered spider silk-dentin matrix protein 1 chimeric protein on hydroxyapatite nucleation, Biomaterials 28 (2007) 2358-2367.

[12] J. Zhu, R.E. Marchant, Design properties of hydrogel tissue-engineering scaffolds, Expert Rev. Med. Devices 8 (2011) 607-626.

[13] B.M. Gumbiner, Cell adhesion: the molecular basis of tissue architecture and morphogenesis, Cell 84 (1996) 345-357.
[14] A.A. Khalili, R.M. Ahmad, A review of cell adhesion studies for biomedical and biological applications, Int. J. Mol. Sci. 16 (2015).

[15] B. Steffensen, X. Xu, P.A. Martin, G. Zardeneta, Human fibronectin and MMP-2 collagen binding domains compete for collagen binding sites and modify cellular activation of MMP-2, Matrix Biol. 21 (2002) 399-414.

[16] S. Ravi, J.M. Caves, A.W. Martinez, C.A. Haller, E.L. Chaikof, Incorporation of fibronectin to enhance cytocompatibility in multilayer elastin-like protein scaffolds for tissue engineering, J. Biomed. Mater. Res. A 101A (2013) 19151925.

[17] K. Skorstengaard, T.L. Holtet, M. Etzerodt, H.C. Thøgersen, Collagen-binding recombinant fibronectin fragments containing type II domains, FEBS Lett. 343 (1994) 47-50.

[18] R. Pankov, K.M. Yamada, Fibronectin at a glance, J. Cell Sci. 115 (2002) 3861 3863.

[19] I.U. Ali, Structural analysis of fibronectin and its collagen-binding fragment from several cell lines, Proc. Natl. Acad. Sci. U.S.A. 81 (1984) 28-32.

[20] Y. Mao, J.E. Schwarzbauer, Fibronectin fibrillogenesis, a cell-mediated matrix assembly process, Matrix Biol. 24 (2005) 389-399.

[21] A.A. Bocquier, J.R. Potts, A.R. Pickford, I.D. Campbell, Solution structure of a pair of modules from the gelatin-binding domain of fibronectin, Structure 7 (1999) S1451-S1453.

[22] Catherine E. Napper, K. Drickamer, Maureen E. Taylor, Collagen binding by the mannose receptor mediated through the fibronectin type II domain, Biochem J. 395 (2006) 579-586.

[23] O.A. Ozhogina, M. Trexler, L. Bányai, M. Llinás, L. Patthy, Origin of fibronectin type II (FN2) modules: structural analyses of distantly-related members of the kringle family idey the kringle domain of neurotrypsin as a potential link between FN2 domains and kringles, Protein Sci. 10 (2001) 2114-2122.

[24] L. Bányai, H. Tordai, L. Patthy, The gelatin-binding site of human 72 kDa type IV collagenase (gelatinase A), Biochem J. 298 (1994) 403-407.

[25] K. Briknarová, A. Grishaev, L. Bányai, H. Tordai, L. Patthy, M. Llinás, The second type II module from human matrix metalloproteinase 2: structure, function and dynamics, Structure 7 (1999). 1235-S1232.

[26] G. Murphy, Q. Nguyen, M.I. Cockett, S.J. Atkinson, J.A. Allan, C.G. Knight, F. Willenbrock, A.J. Docherty, Assessment of the role of the fibronectin-like domain of gelatinase A by analysis of a deletion mutant, J. Biol. Chem. 269 (1994) 6632-6636.

[27] H. Tordai, L. Patthy, The gelatin-binding site of the second type-II domain of gelatinase A/MMP-2, Eur. J. Biochem. 259 (1999) 513-518.

[28] C. Vendrely, T. Scheibel, Biotechnological production of spider-silk proteins enables new applications, Macromol. Biosci. 7 (2007) 401-409.

[29] S. Winkler, D.L. Kaplan, Molecular biology of spider silk, Rev. Mol. Biotechnol. 74 (2000) 85-93.

[30] S. Arcidiacono, C. Mello, D. Kaplan, S. Cheley, H. Bayley, Purification and characterization of recombinant spider silk expressed in Escherichia coli, Appl. Microbiol. Biotechnol. 49 (1998) 31-38.

[31] S.R. Fahnestock, S.L. Irwin, Synthetic spider dragline silk proteins and their production in Escherichia coli, Appl. Microbiol. Biotechnol. 47 (1997) 23-32.

[32] C.W.P. Foo, D.L. Kaplan, Genetic engineering of fibrous proteins: spider dragline silk and collagen, Adv. Drug Del. Rev. 54 (2002) 1131-1143.

[33] G. Candelas, T. Candelas, A. Ortiz, O. Rodriguez, Translational pauses during a spider fibroin synthesis, Biochem. Biophys. Res. Commun. 116 (1983) 1033 1038.

[34] C.W.P. Foo, E. Bini, J. Huang, S.Y. Lee, D.L. Kaplan, Solution behavior of synthetic silk peptides and modified recombinant silk proteins, Appl. Phys. A 82 (2006) 193-203.

[35] O.S. Rabotyagova, P. Cebe, D.L. Kaplan, Role of polyalanine domains in $\beta$-sheet formation in spider silk block copolymers, Macromol. Biosci. 10 (2010) 49-59.

[36] R. Machado, J. Azevedo-Silva, C. Correia, T. Collins, F.J. Arias, J.C. RodríguezCabello, M. Casal, High level expression and facile purification of recombinant silk-elastin-like polymers in auto induction shake flask cultures, AMB Express 3 (2013). 11-11.

[37] T. Collins, M. Barroca, F. Branca, J. Padrão, R. Machado, M. Casal, High leve biosynthesis of a silk-elastin-like protein in E. coli, Biomacromolecules 15 (2014) 2701-2708.

[38] R. Machado, A.D. Costa, V. Sencadas, C. Garcia-Arévalo, C.M. Costa, J. Padrão, A. Gomes, S. Lanceros-Méndez, J.C. Rodríguez-Cabello, M. Casal, Electrospun silkelastin-like fibre mats for tissue engineering applications, Biomed. Mater. 8 (2013) 065009.

[39] R. Machado, A. Da Costa, V. Sencadas, A.M. Pereira, T. Collins, J.C. RodríguezCabello, S. Lanceros-Méndez, M. Casal, Exploring the properties of genetically engineered silk-elastin-like protein films, Macromol. Biosci. (2015) 16981709.

[40] O.S. Rabotyagova, P. Cebe, D.L. Kaplan, Self-assembly of genetically engineered spider silk block copolymers, Biomacromolecules 10 (2009) 229-236.

[41] T. Collins, J. Azevedo-Silva, A. Da Costa, F. Branca, R. Machado, M. Casal, Batch production of a silk-elastin-like protein in E. coli BL21(DE3): key parameters for optimisation, Microb. Cell Fact. 12 (2013).

[42] A. Dong, P. Huang, W.S. Caughey, Protein secondary structures in water from second-derivative amide I infrared spectra, Biochemistry 29 (1990) 3303-3308.

[43] K. Griebenow, A.M. Klibanov, Lyophilization-induced reversible changes in the secondary structure of proteins, Proc. Natl. Acad. Sci. U.S.A. 92 (1995) 10969 10976.

[44] P. Taddei, P. Monti, Vibrational infrared conformational studies of mode peptides representing the semicrystalline domains of Bombyx mori silk fibroin, Biopolymers 78 (2005) 249-258. 
[45] H. Yang, S. Yang, J. Kong, A. Dong, S. Yu, Obtaining information about protein secondary structures in aqueous solution using Fourier transform IR spectroscopy, Nat. Protocols 10 (2015) 382-396.

[46] J.L. Arrondo, A. Muga, J. Castresana, F.M. Goni, Quantitative studies of the structure of proteins in solution by Fourier-transform infrared spectroscopy, Prog. Biophys. Mol. Biol. 59 (1993) 23-56.

[47] C. Jung, Insight into protein structure and protein-ligand recognition by Fourier transform infrared spectroscopy, J. Mol. Recognit. 13 (2000) 325-351.

[48] X. Hu, D. Kaplan, P. Cebe, Determining beta-sheet crystallinity in fibrous proteins by thermal analysis and infrared spectroscopy, Macromolecules 39 (2006) 6161-6170.

[49] J. Steczko, G.A. Donoho, J.E. Dixon, T. Sugimoto, B. Axelrod, Effect of ethano and low-temperature culture on expression of soybean lipoxygenase L- 1 in Escherichia coli, Protein Expression Purif. 2 (1991) 221-227.

[50] F.W. Studier, Protein production by auto-induction in high density shaking cultures, Protein Expression Purif. 41 (2005) 207-234.

[51] H.A. Currie, O. Deschaume, R.R. Naik, C.C. Perry, D.L. Kaplan, Genetically engineered chimeric silk-silver binding proteins, Adv. Funct. Mater. 21 (2011) 2889-2895.

[52] S. Gomes, I.B. Leonor, J.F. Mano, R.L. Reis, D.L. Kaplan, Spider silk-bone sialoprotein fusion proteins for bone tissue engineering, Soft Matter 7 (2011) 4964-4973.

[53] K. Numata, B. Subramanian, H.A. Currie, D.L. Kaplan, Bioengineered silk protein-based gene delivery systems, Biomaterials 30 (2009) 5775-5784.

[54] M. Gehrmann, K. Briknarová, L. Bányai, L. Patthy, M. Llinás, The Col-1 module of human matrix metalloproteinase-2 (MMP-2): structural/functiona relatedness between gelatin-binding fibronectin type II modules and lysinebinding kringle domains, Biol. Chem. 383 (2002) 137.

[55] W. Teng, Y. Huang, J. Cappello, X. Wu, Optically transparent recombinant silkelastinlike protein polymer films, J. Phys. Chem. B 115 (2011) 1608-1615.

[56] D. Wilson, R. Valluzzi, D. Kaplan, Conformational transitions in model silk peptides, Biophys. J. 78 (2000) 2690-2701.

[57] W.K. Surewicz, H.H. Mantsch, D. Chapman, Determination of protein secondary structure by Fourier transform infrared spectroscopy: a critical assessment, Biochemistry 32 (1993) 389-394.

[58] S. Krimm, J. Bandekar, Vibrational spectroscopy and conformation of peptides, polypeptides, and proteins, Adv. Protein Chem. 38 (1986) 181-364.

[59] J. Bandekar, Amide modes and protein conformation, Biochim. Biophys. Acta 1120 (1992) 123-143.

[60] A. Barth, Infrared spectroscopy of proteins, Biochim. Biophys. Acta 1767 (2007) 1073-1101.

[61] J.L.R. Arrondo, F.M. Goñi, Structure and dynamics of membrane proteins as studied by infrared spectroscopy, Prog. Biophys. Mol. Biol. 72 (1999) 367-405.

[62] J. Kong, S. Yu, Fourier transform infrared spectroscopic analysis of protein secondary structures, Acta Biochim. Biophys. Sin. 39 (2007) 549-559.

[63] H. Susi, D. Michael, Byler. Protein structure by Fourier transform infrared spectroscopy: second derivative spectra, Biochem. Biophys. Res. Commun. 115 (1983) 391-397.

[64] E. Goormaghtigh, V. Cabiaux, J.-M. Ruysschaert, Secondary structure and dosage of soluble and membrane proteins by attenuated total reflection Fourier-transform infrared spectroscopy on hydrated films, Eur. J. Biochem. 193 (1990) 409-420.

[65] M. Jackson, H.H. Mantsch, The use and misuse of FTIR spectroscopy in the determination of protein structure, Crit. Rev. Biochem. Mol. Biol. 30 (1995) 95120.

[66] E.A. Cavalcanti-Adam, A. Micoulet, J. Blümmel, J. Auernheimer, H. Kessler, J.P. Spatz, Lateral spacing of integrin ligands influences cell spreading and foca adhesion assembly, Eur. J. Cell Biol. 85 (2006) 219-224.

[67] E.A. Cavalcanti-Adam, T. Volberg, A. Micoulet, H. Kessler, B. Geiger, J.P. Spatz, Cell spreading and focal adhesion dynamics are regulated by spacing of integrin ligands, Biophys. J. 92 (2007) 2964-2974.
[68] G. Le Saux, A. Magenau, T. Böcking, K. Gaus, J.J. Gooding, The relative importance of topography and RGD ligand density for endothelial cell adhesion, PLoS ONE 6 (2011) e21869.

[69] G. Le-saux, A. Magenau, K. Gunaratnam, Kristopher A. Kilian, T. Böcking, J.J. Gooding, K. Gaus, Spacing of integrin ligands influences signal transduction in endothelial cells, Biophys. J. 101 (2011) 764-773.

[70] X. Wang, K. Ye, Z. Li, C. Yan, J. Ding, Adhesion, proliferation, and differentiation of mesenchymal stem cells on RGD nanopatterns of varied nanospacings, Organogenesis 9 (2013) 280-286.

[71] D.A. Calderwood, S.J. Shattil, M.H. Ginsberg, Integrins and actin filaments: reciprocal regulation of cell adhesion and signaling, J. Biol. Chem. 275 (2000) $22607-22610$

[72] J.I.M. Glass, J.O.N. Blevitt, K.E.N. Dickerson, M. Pierschbacher, W.S. Craig, Cell attachment and motility on materials modified by surface-active RGD-containing peptides, Ann. N. Y. Acad. Sci. 745 (1994) 177-186.

[73] R. Rajaraman, D.E. Rounds, S.P.S. Yen, A. Rembaum, A scanning electron microscope study of cell adhesion and spreading in vitro, Exp. Cell Res. 88 (1974) 327-339.

[74] J. Albuschies, V. Vogel, The role of filopodia in the recognition of nanotopographies, Sci. Rep. 3 (2013) 1658.

[75] M.A. Partridge, E.E. Marcantonio, Initiation of attachment and generation of mature focal adhesions by integrin-containing filopodia in cell spreading, Mol. Biol. Cell 17 (2006) 4237-4248.

[76] T.A. Blackledge, C.Y. Hayashi, Unraveling the mechanical properties of composite silk threads spun by cribellate orb-weaving spiders, J. Exp. Biol. 209 (2006) 3131-3140.

[77] T.A. Blackledge, J.E. Swindeman, C.Y. Hayashi, Quasistatic and continuous dynamic characterization of the mechanical properties of silk from the cobweb of the black widow spider, J. Exp. Biol. 208 (2005) 1937-1949.

[78] N. Du, Z. Yang, X.Y. Liu, Y. Li, H.Y. Xu, Structural origin of the strain-hardening of spider silk, Adv. Funct. Mater. 21 (2011) 772-778.

[79] M. Haider, V. Leung, F. Ferrari, J. Crissman, J. Powell, J. Cappello, H. Ghandehari, Molecular engineering of silk-elastinlike polymers for matrix-mediated gene delivery: biosynthesis and characterization, Mol. Pharm. 2 (2005) 139-150.

[80] O.S. Rabotyagova, P. Cebe, D.L. Kaplan, Protein-based block copolymers, Biomacromolecules 12 (2011) 269-289.

[81] S.E. Sakiyama-Elbert, J.A. Hubbell, Functional biomaterials: design of novel biomaterials, Annu. Rev. Mater. Res. 31 (2001) 183-201.

[82] I. Engelberg, J. Kohn, Physico-mechanical properties of degradable polymers used in medical applications: a comparative study, Biomaterials 12 (1991) 292-304.

[83] K. Hu, Q. Lv, F.Z. Cui, Q.L. Feng, X.D. Kong, H.L. Wang, L.Y. Huang, T. Li, Biocompatible fibroin blended films with recombinant human-like collagen for hepatic tissue engineering. J. Bioact. Compat. Polym. 21 (2006) 23-37.

[84] C.L. Tucker, J.A. Jones, H.N. Bringhurst, C.G. Copeland, J.B. Addison, W.S. Weber, Q. Mou, J.L. Yarger, R.V. Lewis, Mechanical and physical properties of recombinant spider silk films using organic and aqueous solvents, Biomacromolecules 15 (2014) 3158-3170.

[85] K. Spiess, R. Ene, C.D. Keenan, J. Senker, F. Kremer, T. Scheibel, Impact of initial solvent on thermal stability and mechanical properties of recombinant spider silk films, J. Mater. Chem. 21 (2011) 13594-13604.

[86] E. Goormaghtigh, J.-M. Ruysschaert, V. Raussens, Evaluation of the information content in infrared spectra for protein secondary structure determination, Biophys. J. 90 (2006) 2946-2957.

\section{Further reading}

[87] K. Briknarová, M. Gehrmann, L. Bányai, H. Tordai, L. Patthy, M. Llinás, Gelatin-binding region of human matrix metalloproteinase-2: solution structure, dynamics, and function of the Col-23-tow-domain construct, J. Biol. Chem. 276 (2001) 27613-27621. 